\title{
THE EFFECT OF PRODUCT QUALITY AND PRODUCT INNOVATION ON CONSUMER LOYALTY IN FIZZUL PUTRA MANDIRI CONVECTION, JOMBANG REGENCY
}

\author{
Rahayu Somalua ${ }^{*}$, Asim $^{2}$, Nurminingsih $^{3}$, Robert Siregar $^{4}$ \\ ${ }^{1,2,3,4}$ Universitas Respati Indonesia \\ E-mail: ${ }^{1)}$ somaluarahayu@gmail.com, ${ }^{2)}$ Acim_madu1@yahoo.com, ${ }^{3)}$ Nings@urindo.ac.id, \\ 4) Robertyanti715@gmal.com
}

\begin{abstract}
The purpose of this study is to analyze the effect of Product Quality and Product Innovation on Consumer Loyalty of Fizzul Putra Mandiri Convection, Jombang Regency. This research is a quantitative study, while the population in this study are consumers from the Fizzul Putra Mandiri Convection Jombang regency, which are included in the population of regular (customers) in which the sample to be taken is known with certainty, resulting as many as 85 regular consumers. The data was obtained using a questionnaire, the data was processed using the Structural Equation Model (SEM) or SmartPLS 3 software. The results reveal that product quality has an insignificant positive effect on consumer loyalty, which means that the higher the product quality, the higher the consumer loyalty, but the increase in consumer loyalty caused by product quality is not significant. Therefore, increasing product quality only slightly increases consumer loyalty, decreasing product quality only slightly decreases consumer loyalty. Meanwhile, product innovation has a positive and significant effect on consumer loyalty, which means the higher the product innovation, the higher the consumer loyalty and vice versa. Besides that, product quality has a positive and significant effect on product innovation, which means that the higher the product quality, the higher the product innovation, and the lower the product quality will result the lower the product innovation as well.
\end{abstract}

Keywords: Product Quality, Product Innovation, Consumer Loyalty

\section{INTRODUCTION}

The actions of businesses that provide both services and goods are directed toward the same end, namely, profit maximization. Additionally, the company strives to ensure that customers are satisfied with the items it produces, as customer satisfaction is a key indicator of a company's ability to generate high-quality products. One of the organizations can recognize the importance of the marketing component in producing the best and most appropriate marketing strategy to be implemented. Because marketing is one of the most crucial market opportunities in consumer considerations when making purchasing decisions for a product, it is critical to understand how marketing works. Without being attentive to the needs of consumers, it is almost guaranteed that the firm will lose many possibilities to acquire customers and that the items it offers would be in vain if it does not adapt its business practices.

Consumer demands are a crucial and primary issue for every business, and this is especially true in the convection business, given the fact that numerous convection enterprises are competing with one another to gain consumer loyalty and satisfaction. Providing excellent services or products at competitive prices will help the convection 
business build a solid and loyal customer base in this competitive environment, which will increase the likelihood of obtaining new customers in the long run. Satisfied customers are a strong indicator that these customers are likely to be loyal to the company and purchase from them again in the future ((Farisi \& Siregar, 2020); (Simanjuntak \& Purba, 2020)).

Convection business is defined as a business field that manufactures clothing in large quantities based on demand. Due to shifting fashion trends as well as the function of clothes, the convection business is a very promising business sector with enormous profit potential. Clothing is not only a fundamental necessity, but it is also a way of life. In Indonesia, the convection business is expanding at a quick pace as a result of strong market demand, particularly in Jombang Regency. Consumer loyalty is important to Fizzul Putra Mandiri convection as a convection business that wants to preserve and increase customer loyalty.

Fizzul Putra Mandiri Convection is more concerned with or prioritizing the quality of better service, so the products provided by the Fizzul Putra Mandiri convection are school uniforms, sports shirts and batik uniforms. The manufacture of school uniforms, t-shirts and batik uniforms related to schools is the main business of Fizzul Putra Mandiri Convection which is developed and upholds work responsibilities so as to provide good service to every consumer. Fizzul Putra Mandiri Convection business has now started to propagate in shorts, jackets and t-shirts product. As for marketing, there are several areas in the eastern part (Sulawesi, North Maluku and Maluku).

Convection commodities are products that always have demand from the public for household, office, industrial and government needs. Behind the promising business potential, there are also problems faced by business actors, especially Fizzul Putra Mandiri convection in the form of fluctuations in raw material prices so that it affects production capacity and has the potential to cause business capital to shrink rapidly. This condition results in an increase in the price of convection products making it difficult to compete with competitors, especially imported convection, as well as from the consumer side who will turn to cheap and quality consumer products.

The importance of efforts to increase consumer loyalty is important to identify factors or variables that directly affect consumer loyalty. The first variable is product quality, which is a marketing strategy that seeks to differentiate a business's product or service from the competition (Ibad et al., 2018). Successful product quality begins with identifying and creating the unique qualities of the offering while observing the differences between the offering and competitors. Product quality goes hand in hand with developing a strong value proposition to make the product more attractive to the market.

\section{LITERATURE REVIEW}

\subsection{Product Quality}

Product quality is one of the primary criteria that buyers expect from manufacturers. Quality, according to the American Society for Quality Control, is the sum of a product's or service's qualities and attributes that affect its capacity to satisfy stated or implied needs.

According to Philip Kotler \& Keller (2012) product quality is the totality of features and characteristics of a product or service that has the ability to satisfy or what is called an implied need. Further, Philip Kotler \& Armstrong (2010) highlight that product quality is a characteristic of a product or service whose ability to survive to meet stated customer needs. 


\section{JOURNAL OF MANAGEMENT, ACCOUNTING, GENERAL FINANCE AND INTERNATIONAL ECONOMIC ISSUES (MARGINAL) \\ VOLUME 1 ISSUE 2 (2022)}

Dimensions of quality according to Garvin in (Nasution, 2017) there are 7 dimensions of quality, including:

1) Performance, related to the functional aspects of the product and is the main characteristic that customers consider when they want to buy a product.

2) Features, is the second aspect of performance that adds to the basic functionality with regard to options and development.

3) Reliability is related to the possibility of a product to function successfully in a certain period under certain conditions.

4) Conformance, relates to the level of product conformity to predetermined specifications based on customer desires.

5) Durability is a measure of the lifetime of a product. Service Ability, is a characteristic related to speed/politeness, competence, convenience, and accuracy in repairs.

6) Aesthetics is a subjective characteristic of beauty that is related to personal considerations and reflections of individual preferences or choices.

7) Perceived Quality, is subjective, related to customer feelings in consuming products, such as increasing self-esteem.

\subsection{Product Innovation}

Innovation is one of the choices of corporations in facing market competition and sustainable management. According to Carbonell \& Rodriguez (2006) stated that innovation as the efforts of the company through the use of technology and information to develop, produce and market new products for the business. In other words, innovation is the modification or discovery of ideas for continuous improvement and development to meet customer needs.

Meanwhile, Dachi (2020) explain that stakeholder involvement in innovations implemented by entrepreneurs as a form of entrepreneurship development. Recent research explains that innovation is not only limited to products and services but innovation in technological aspects through the concept of innovation that provides opportunities for individuals to discover, develop, deploy, and disseminate decentralized applications that revolutionize entrepreneurship.

Furthermore, Lukas and Ferrell (in Dachi, 2020) explain that there are several indicators of product innovation, namely:

1) Line extensions, namely the products produced by the company are not really new but are relatively new to a market.

2) A new product (me too-product) is a product that is new to the company but not new to the market.

3) A completely new product (new - to - the - world - product) is a product that is new to both the company and the market.

\subsection{Consumer Loyalty}

According to Rangkuti (2000) states that "Consumer loyalty is consumer loyalty to the company, brand or product. Meanwhile, Sutisna (2013) defines loyalty as a favorable attitude towards a brand that is represented in consistent purchases of that brand over time. According to Tjiptono (2007), "customer loyalty is a customer's commitment to a brand, store or supplier based on a very positive nature in long-term purchases". 
Loyalty to the brand is obtained because of a combination of satisfaction and complaints. Meanwhile, customer satisfaction comes from how much the company's performance is to generate satisfaction by minimizing complaints so that long-term purchases are made by consumers.

There are indicators of customer loyalty according to Kotler \& Keller (2012), namely :

1) Repeat Purchase (Repurchase of the product),

2) Retention (Resistance to negative influences about the product), and

3) Referrals (Referring to others).

\section{RESEARCH METHOD}

This type of research is a type of quantitative research where this study aims to find the relationship and influence between one variable and another. Sugiyono (2014) states that quantitative research is research that aims to determine the relationship between two or more variables. This research was conducted at the Fizzul Putra Mandiri convection, Jombang district, Jl. Adji Sastro Widoyo, kaflingan 23.24, klagen, kepuh flower, paterongan, East Java province. Meanwhile, the research was carried out for \pm 4 (four) months, namely from April to July 2021.

For the total population of consumers from the Fizzul Putra Mandiri Convection, Jombang Regency is included in the permanent consumer population (customers). Determination of the number of samples to be taken is known for certain, namely as many as 85 regular consumers, which obtained based on information from Fizzul Putra Mandiri Convection. The method of determining the sample using the saturated sample method is that the entire sample population is used as a respondent.

This research uses data analysis method using SmartPLS version 3 software which is run on computer media. According to Jogiyanto \& Abdillah (2015) PLS (Partial Least Square) is a variant-based structural equation analysis (SEM) that can simultaneously test the measurement model as well as test the structural model. The measurement model is used to test the validity and reliability, while the structural model is used to test causality (testing hypotheses with predictive models).

\section{RESULT AND DISCUSSION}

\subsection{Research Results}

This research uses data analysis method using SmartPLS version 3 software which is run on computer media. According to Jogiyanto \& Abdillah (2015) PLS (Partial Least Square) is a variant-based structural equation analysis (SEM) that can simultaneously test the measurement model as well as test the structural model. The measurement model is used to test the validity and reliability, while the structural model is used to test causality (testing hypotheses with predictive models). The testing stages are the outer model, to determine the validity and reliability tests which include convergent validity, discriminant validity, composite reliability, average variance extracted, Cronbach's alpha, while inner model includes r-square test and hypothesis testing. 


\section{JOURNAL OF MANAGEMENT, ACCOUNTING, GENERAL \\ FINANCE AND INTERNATIONAL ECONOMIC ISSUES \\ (MARGINAL) \\ VOLUME 1 ISSUE 2 (2022)}

Based on the research that has been done, the results of the Outer Model for Validity Test are obtained in the image below:

4.1.1. Evaluation of Measurement (Outer) Model

1) Validity test

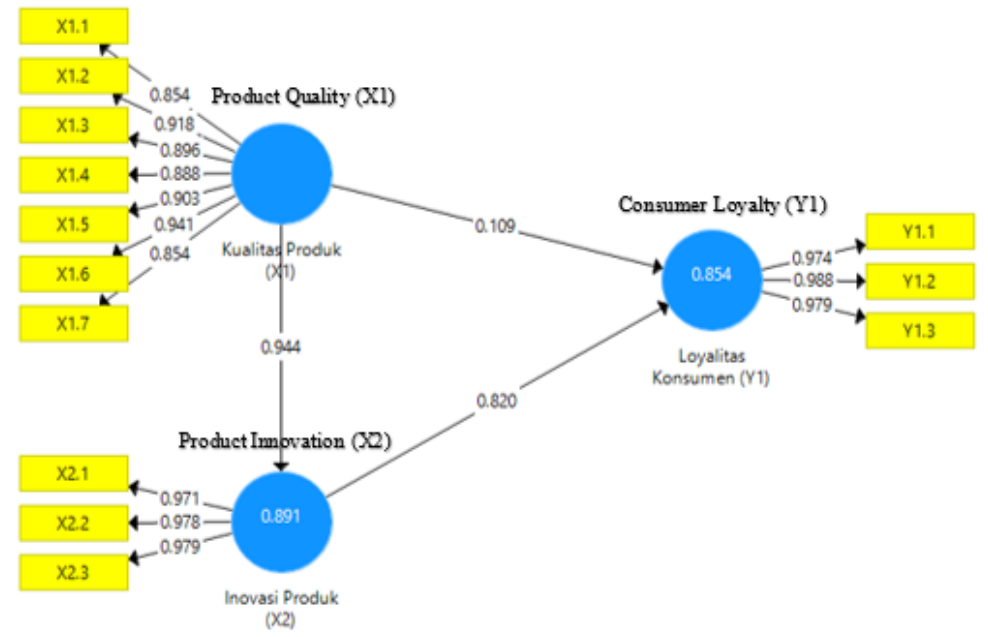

Figure 1 Loading Factor Value

a. Discriminant Validity

Table 1 Cross Loading

\begin{tabular}{lccc}
\hline & $\begin{array}{c}\text { Product Quality } \\
(\mathbf{X} 1)\end{array}$ & $\begin{array}{c}\text { Product } \\
\text { Innovation }(\mathbf{X 2})\end{array}$ & $\begin{array}{c}\text { Consumer Loyalty } \\
(\mathbf{Y} 1)\end{array}$ \\
\hline $\mathbf{X 1 . 1}$ & 0.854 & 0.709 & 0.656 \\
\hline $\mathbf{X 1 . 2}$ & 0.918 & 0.841 & 0.817 \\
\hline $\mathbf{X 1 . 3}$ & 0.896 & 0.822 & 0.772 \\
\hline $\mathbf{X 1 . 4}$ & 0.888 & 0.890 & 0.803 \\
\hline $\mathbf{X 1 . 5}$ & 0.903 & 0.830 & 0.731 \\
\hline $\mathbf{X 1 . 6}$ & 0.941 & 0.925 & 0.850 \\
\hline $\mathbf{X 1 . 7}$ & 0.854 & 0.861 & 0.869 \\
\hline $\mathbf{X 2 . 1}$ & 0.971 & 0.914 & 0.844 \\
\hline $\mathbf{X 2 . 2}$ & 0.978 & 0.921 & 0.951 \\
\hline $\mathbf{X 2 . 3}$ & 0.979 & 0.928 & 0.906 \\
\hline Y1.1 & 0.903 & 0.859 & 0.974 \\
\hline Y1.2 & 0.917 & 0.870 & 0.988 \\
\hline Y1.3 & 0.896 & 0.870 & 0.979 \\
\hline
\end{tabular}

b. Average Variance Extracted (AVE)

Table 2 Average Variance Extracted (AVE) Value

\begin{tabular}{cc}
\hline & Average Variance Extracted (AVE) \\
\hline Product Quality (X1) & 0.799 \\
\hline Product Innovation (X2) & 0.952 \\
\hline Consumer Loyalty (Y1) & 0.961 \\
\hline
\end{tabular}

2) Reliability Test 
Table 3 Composite Reliability

\begin{tabular}{cc}
\hline & Composite Reliability \\
\hline Product Quality (X2) & 0.983 \\
\hline Product Innovation (X1) & 0.965 \\
\hline Consumer Loyalty (Y1) & 0.987 \\
\hline
\end{tabular}

Table 4 Cronbach's Alpha

\begin{tabular}{cc}
\hline & Cronbach's Alpha \\
\hline Product Quality (X2) & 0.973 \\
\hline Product Innovation (X1) & 0.975 \\
\hline Consumer Loyalty (Y1) & 0.98 \\
\hline
\end{tabular}

\subsubsection{Structural Model Testing (Inner Model)}

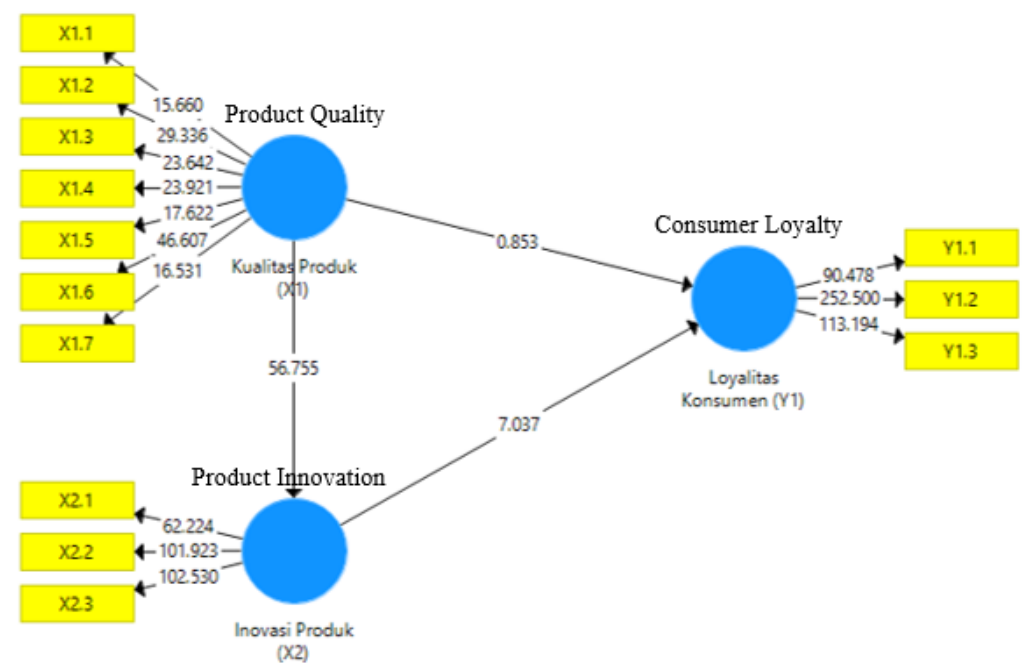

Figure 2 Validity Test, T-Statistic

a. R-Square

Table 5 R-Square

\begin{tabular}{ccc}
\hline & R Square & R Square Adjusted \\
\hline Product Innovation (X2) & 0.891 & 0.890 \\
\hline Consumer Loyalty (Y1) & 0.854 & 0.851 \\
\hline
\end{tabular}

\section{b. Hypothesis Test Results}

Table 6 Hypothesis Test Results

\begin{tabular}{lccccc}
\hline & $\begin{array}{c}\text { Original } \\
\text { Sample } \\
(\mathbf{O})\end{array}$ & $\begin{array}{c}\text { Sample } \\
\text { Mean } \\
(\mathbf{M})\end{array}$ & $\begin{array}{c}\text { Standard } \\
\text { Deviation } \\
(\text { STDEV) }\end{array}$ & $\begin{array}{c}\text { T Statistics } \\
(|\mathbf{O} / \mathbf{S T D E V}|)\end{array}$ & $\begin{array}{c}\text { P } \\
\text { Values }\end{array}$ \\
\hline $\begin{array}{l}\text { Product Quality (X1) } \\
\text { Consumer Loyalty (Y1) }\end{array}$ & 0.109 & 0.080 & 0.128 & 0.853 & 0.394 \\
\hline $\begin{array}{l}\text { Product Innovation (X2) -> } \\
\text { Consumer Loyalty (Y1) }\end{array}$ & 0.820 & 0.851 & 0.117 & 7.037 & 0.000 \\
\hline
\end{tabular}


VOLUME 1 ISSUE 2 (2022)

\begin{tabular}{lllllll}
\hline $\begin{array}{l}\text { Product Quality (X1) } \\
\text { Product Innovation (X2) }\end{array}$ & 0.944 & 0.945 & 0.017 & 56,755 & 0.000 \\
\hline
\end{tabular}

\subsection{Discussion}

\subsubsection{The Effect of Product Quality on Consumer Loyalty}

According to Table 5, it shows that the relationship between Product Quality (X1) and Consumer Loyalty (Y) is significant with a T-Statistic of $0,834(>1,96)$. The original sample estimate value is positive, namely 0,109 which indicates the relationship between Product Quality (X1) and Consumer Loyalty (Y) is positive. Thus, the hypothesis H1 in this study was rejected. As a result, Product Quality has no significant effect on Consumer Loyalty. This shows the relationship between product quality and consumer loyalty has a positive relationship. Hence, it can be concluded that the higher the quality of the product, the higher the consumer loyalty.

\subsubsection{The Effect of Product Innovation on Consumer Loyalty}

According to Table 5, it shows that the relationship between Product Innovation (X2) and Consumer Loyalty (Y) is significant with a T-Statistic of 3,938 $(>1,96)$. The original sample estimate value is positive, namely 0,769 which indicates the relationship between Product Innovation (X2) and Consumer Loyalty (Y) is positive. Thus, the hypothesis H2 in this study which states that Product Innovation (X2) has an effect on Sales Volume (Y) is accepted.

\subsubsection{Effect of Product Quality on Product Innovation}

According to Table 5, it shows that the relationship between Product Quality (X1) and Product Innovation (X2) is significant with a T-Statistic of $69,168(>1,96)$. The original sample estimate value is positive, which is 0,962 which indicates the relationship between Product Quality (X1) and Product Innovation (X2) is positive. Thus, the hypothesis H3 in this study which states that Product Quality (X1) has an effect on Product Innovation (X2) is accepted.

\section{CONCLUSION}

Based on the results of the SEM (Structural Equation Modeling) analysis and the discussions that have been carried out in this study, there are the following conclusions:

1. Product quality has no significant positive effect on consumer loyalty. These results indicate that although product quality has no significant effect on consumer loyalty, but it has an affordable price. Since the convection already has regular customers. Which means that the higher the quality of the product, the higher the consumer loyalty.

2. Product quality has a positive and significant effect on consumer loyalty. This means that the higher the product quality, the higher the product innovation. The lower the product quality, the lower the product innovation as well.

3. Product quality has a positive and significant effect on product innovation. This means that the higher the product quality, the higher the product innovation. The lower the product quality, the lower the product innovation as well. 


\section{Suggestions} follows:

Based on the research results obtained, the suggestions given by the author are as

1. Hopefully, Fizzul Putra Mandiri Convection will always maintain and increase the durability of its convection products. The company should always pay attention to the resistance of the material for making clothes and also screen printing so that it is not easily damaged and also does not easily fade. In order for the loyalty of consumers to survive.

2. Fizzul Putra Mandiri Convection should always conduct research and product development so that it succeeds in creating new products that can be accepted by the community. In the convection industry, product innovation is very important. Product innovation is very important for the convection industry to survive. The ever-changing fashion trends force the convection industry such as Fizzul Putra Mandiri convection to always innovate.

3. Companies should always maintain product quality so that it is always good. Since the product quality has an effect on product innovation, which means the better the product quality, the more variations of new products produced by Fizzul Putra Mandiri convection, which can then bring profits to the company.

\section{REFERENCES}

Carbonell, P., \& Rodriguez, A. I. (2006). The impact of market characteristics and innovation speed on perceptions of positional advantage and new product performance. International Journal of Research in Marketing, 23(1), 1-12.

Dachi, A. (2020). Inovasi Produk terhadap Keputusan Pembelian dan dampaknya terhadap loyalitas pelanggan: Studi Pengguna Mobil Toyota Calya di Kota Bogor dan Bekasi. JSHP: Jurnal Sosial Humaniora Dan Pendidikan, 4(2), 120-129.

Farisi, S., \& Siregar, Q. R. (2020). Pengaruh Harga dan Promosi Terhadap Loyalitas Pelanggan Pengguna Jasa Transportasi Online di Kota Medan. Maneggio: Jurnal Ilmiah Magister Manajemen, 3(1), 148-159.

Ibad, S., Arifin, R., \& Priyono, A. A. (2018). Pengaruh Bauran Pemasaran Jasa (Product, Price, Place, Promotion, Process, People, And Physical Evidence) Terhadap Keputusan Pembelian (Study Kasus Pada Jasa Transportasi CV King Tour And Travel). Jurnal Ilmiah Riset Manajemen, 7(02).

Jogiyanto, H., \& Abdillah, W. (2015). Partial least square (PLS) : alternatif structural equation modeling (SEM) dalam penelitian bisnis. Yogyakarta: Andi Offset.

Kotler, P, \& Keller, K. . (2012). Marketing Management, 14th ed., Pearson Education, Upper Saddle River, NJ.

Kotler, Philip, \& Armstrong, G. (2010). Principles of marketing. Pearson education.

Kotler, Philip, \& Keller, K. L. (2012). Marketing Management: Philip Kotler, Kevin Lane Keller. Pearson.

Nasution, Y. (2017). Analisis Pengaruh Rasio Keuangan Terhadap Pertumbuhan Laba Pada Perusahaan Manufaktur Sektor Industri Barang Konsumsi Yang Terdaftar Di Bursa 


\section{JOURNAL OF MANAGEMENT, ACCOUNTING, GENERAL \\ FINANCE AND INTERNATIONAL ECONOMIC ISSUES \\ (MARGINAL) \\ VOLUME 1 ISSUE 2 (2022)}

Efek Indonesia Periode 2011-2016. Universitas Satya Negara Indonesia - Vol 2 No 1 Agustus 2017 Page 33.

Rangkuti, F. (2000). Business plan: teknik membuat perencanaan bisnis dan analisis kasus. Gramedia Pustaka Utama.

Simanjuntak, D. C. Y., \& Purba, P. Y. (2020). Peran Mediasi Customer Satisfaction dalam Customer Experience Dan Loyalitas Pelanggan. Jurnal Bisnis Dan Manajemen, 7(2).

Sugiyono. (2014). Metode Penelitian Pendidikan Pendekatan Kuantitatif, Kualitatif, dan $R \& D$. Alfabeta.

Sutisna, S. (2013). Perilaku konsumen dan komunikasi pemasaran. Jakarta: PT. Remaja Rosdakarya.

Tjiptono, F. (2007). Strategi Pemasaran Edisi ke dua, penerbit Andi. Yogyakarta. 
